\title{
Sağlık Teknikerliği Öğrencilerinin Benlik SaygıSı Düzeyi ve İlişkili Etmenler
}

\author{
Ayla Açıkgöz ${ }^{1 *}$ \\ ${ }^{1}$ Dokuz Eylül Üniversitesi Sağlık Hizmetleri Meslek Yüksekokulu, İzmir, Türkiye \\ email: ayla.acikgoz@deu.edu.tr \\ Orcid: : 0000-0001-7749-705X \\ *Sorumlu Yazar / Corresponding Author: Sorumlu Yazar: Ayla Açıkgöz \\ Gönderim Tarihi / Received: 30.07.2019 \\ Kabul Tarihi / Accepted: 04.12.2019 \\ DOI: $10.34087 /$ cbusbed.598593
}

\begin{abstract}
Amaç: Bu çalışmada sağlık teknikerliği öğrencilerinin benlik saygısı düzeyinin belirlenmesi ve benlik saygısı düzeyinin öğrencilerin sosyodemografik özellikleri, okudukları programa yönelik algı ve tutumları ile ilişkisinin araştırılması amaçlanmıştır.
\end{abstract}

Gereç ve Yöntem: Kesitsel tipteki bu araştırmanın evreni Dokuz Eylül Üniversitesi Sağlık Hizmetleri Meslek Yüksekokulu'nda öğrenim gören öğrencilerden oluşmaktadır. Veriler, literatürden yararlanılarak oluşturulan bir anket ve Rosenberg Benlik Saygısı Ölçeği’yle toplanmıştır. Veriler ki-kare analizi ile değerlendirilmiştir.

Bulgular: Araştırmaya katılan öğrencilerin \%54,6'sının benlik saygısı düzeyi yüksektir. Öğrencilerin cinsiyeti, babasının öğrenim düzeyi, çocuklukta yaşanan yer, ailesinin ekonomik durumu algısı, öğrencinin gelir algısı ve yaşam kalitesi algısı ile yüksek benlik saygısı arasında anlamlı ilişki bulunmuştur $(\mathrm{p}<0,05)$. Okuduğu bölümü isteyerek seçen, kaydını yaptırmadan önce bölümle ilgili ön araştırma yapan, kendini bu mesleğe uygun bulan, mesleğiyle ilgili görev tanımını bilen öğrencilerin benlik saygısı düzeyi daha yüksek bulunmuştur $(p<0,05)$. Mezuniyet sonrası yapacağı mesleğe yönelik kaygısı olmayan öğrencilerin benlik saygısı düzeyi daha yüksektir $(p<0,05)$. Hastalarla iletişimden korkmayanların, mesleği yapabileceğini düşünenlerin ve ağır koşullarda çalışma kaygısı olmayanların benlik saygısı düzeyi daha yüksek bulunmuştur $(\mathrm{p}<0,01)$.

Sonuç: Öğrencilerin sosyodemografik özellikleri, ekonomik durum ve yaşam kalitesi algısı, okudukları programı tercih nedenleri ve programa yönelik olumlu görüşleri ve mesleğe yönelik kaygıları ile yüksek benlik saygısı düzeyi arasında ilişki bulunmuştur. Öğrencilerin benlik saygısının artırılması için ailesel ve eğitsel kökenli ruh sağlığını etkileyen faktörlerin saptanarak koruyucu hizmetlerin bütüncül olarak sunulması önerilir.

Anahtar kelimeler: Benlik saygısı, Üniversite Öğrencisi, Sağlık Teknikerliği Öğrencisi.

Abstract
Objective: In this study, it was aimed to determine the self-esteem level of healthcare technician students and to investigate the relationship between self-esteem level and sociodemographic characteristics of students, their perceptions and attitudes towards the program they studied.

Methods: The population of this cross-sectional study consisted of students from Dokuz Eylül University Vocational School of Health Services. Data were collected using a questionnaire based on the literature and the Rosenberg Self-Esteem Scale. Chi-square test was used for statistical analysis.

Results: Self-esteem level was high in $54.6 \%$ of the students. A significant relationship was found between high self-esteem and students' gender, father's education level, childhood place, family economic perception, individual income perception and quality of life perception $(\mathrm{p}<0.01)$. Self-esteem level was higher in students who chose their department willingly, researched the department before enrolling, considered themselves suitable for this profession, and knew the job description of their profession $(p<0.05)$. Self-esteem level was higher in students who do not have any anxiety about their profession after graduation $(\mathrm{p}<0.05)$. Self-esteem level was higher in students who were not concerned about communicating with patients, thought that they could do the profession, and were not anxious to work under severe conditions $(\mathrm{p}<0.01)$.

Conclusion: Sociodemographic characteristics, economic status and quality of life perception, reasons for choosing the program they studied, positive opinions about the program, and occupational anxieties were found to be related with high self-esteem. It is recommended that the familial and educational factors which affect the mental health of students should be identified and the protective services should be provided as a whole.

Keywords: Self-esteem, University Student, Healthcare Technician Students. 


\section{Giriș}

Benlik kavramı, bireyin özellikleri, kişiliği, kendisi hakkındaki düşüncesi, kendini değerlendirme, algılama ve tanımlama biçimidir. Benlik, bireyi denetleyen, değerlendiren, yargılayan içsel bir güçtür. Bu nedenle benlik kavramının özünde günlük yaşantıyı, davranışları, algıyı ve başarıyı etkileyen kişiye bağlı bir öznellik bulunmaktadır [1].

Benlik saygısı, bireyin kendine atfettiği olumlu ya da olumsuz değerdir [2]. Yakın çevrenin tutumu, hoşnut bırakan ya da düş kırıklığına uğratan olaylar ve yaşantılarla ilişkili olarak bireyde kendine değer verme duygusu gelişmektedir [3]. Benlik saygısı, kişinin kendine saygı duyması kadar kendine güven duyması, kendini benimseyip değer vermesi, kendini onaylaması, kendisinden hoşnut olması, kendini olumlu ve sevilmeye değer bulması gibi pek çok kavramla ifade edilmektedir $[1,2]$. Bireyin benlik saygısı çocuklukta başlamakta, yetiştiği çevreden ve sosyal ilişkilerden etkilenmektedir [1]. Çocuklukta onaylanan davranışlar, çevrenin onun hakkındaki olumlu ya da olumsuz düşüncesi benlik saygısının şekillenmesinde etkili olabilmektedir. Benlik saygısı gençlik yıllarında daha öznel hale gelerek bireyin yaşantısını, davranışlarını ve tercihlerini etkileyen önemli bir faktör haline gelmektedir [1,4]. Benlik saygısı yüksek olan bireyler kendilerini değerli olarak algılamakta, benlik saygısı düşük olan bireyler ise, kendilerini küçük görmekte ve kendilerinden memnun olmadıklarını belirtmektedir $[5,6]$. Benlik saygısını tanımlayan bu özelliklerin tümü, bireyin sağlıklı bir kişilik geliştirmesinde önem kazanmaktadır [5].

Yaptığ 1 iş ile kendini topluma kanıtlamak isteyen gençlerin okudukları programa yönelik görüşleri ve yapacakları mesleğe yönelik kaygıları öğrencilerin benlik saygısı düzeyi ile ilişkili olabilir [7]. Bu nedenle gençlik yıllarındaki benlik saygısının incelenmesi önemli bir konudur. Geleceğin sağlık teknikerlerinin benlik saygısı düzeyini etkileyen etmenlerin mezuniyet öncesi dönemde saptanarak, multidisipliner bir yaklaşımla sorunlara yönelik çözümler aranması bakımından bu çalışma yol gösterici olabilir.

$\mathrm{Bu}$ çalışmada sağlık teknikerliği öğrencilerinin benlik saygısı düzeyinin belirlenmesi ve benlik saygıs1 düzeyinin öğrencilerin sosyodemografik özellikleri, okudukları programa yönelik algı ve tutumları ile ilişkisinin araştırılması amaçlanmıştır.

\section{Gereç ve Yöntem}

Kesitsel tipteki bu araştırma Dokuz Eylül Üniversitesi (DEÜ) Sağlık Hizmetleri Meslek Yüksekokulu'nda (SHMYO) yapılmıştır. Araştırmanın evreni, DEÜ SHMYO'nun dokuz farkl1 programında (T1bbi Dokümantasyon ve Sekreterlik n:118, Tibbi Görüntüleme Teknikleri n:118, Tibbi Laboratuvar Teknikleri n:106, Radyoterapi n:85, İlk ve Acil Yardım n:121, Anestezi n:116, Odyometri n:74, Nükleer T1p Teknikleri n:63, Ağız ve Diş Sağlığı n:42) öğrenim gören öğrencilerden ( $\mathrm{N}=832)$ oluşmaktadır. Araştırmada örneklem seçimi yapılmaksızın evrenin tamamına ulaşılması hedeflenmiştir. Araştırmaya başlamadan önce okul yönetiminden ve DEÜ Girişimsel Olmayan Araştırmalar Etik Kurulu'ndan izin alınmıştır. Veriler literatürden [2,4,7-10] yararlanılarak oluşturulmuş olan bir anket ve Rosenberg Benlik Saygısı Ölçeği $[11,12]$ ile toplanmıştır.

\subsection{Kullanılan Araçlar}

2.1.1 Anket Formu: Öğrencilerin sosyodemografik ve ailesel özellikleri, sağlık durumu ve yaşam kalitesi, bölümü tercih etme ile ilişkili değişkenler, bölümüyle ilgili geleceğe yönelik görüşleri ve kaygı durumunu belirlemeye yönelik 17 sorudan oluşan bir anket formu hazırlanmıştır. Anketler dağıtılmadan önce öğrencilere çalışmanın amacı açıklanmış, araştırmaya katılıp, katılmama konusunda özgür oldukları, araştırma kapsamında verilerin gizli tutulacağı konusunda bilgi verilmiş ve gönüllü onamları alındıktan sonra öğrenciler tarafından anketler doldurulmuştur. Araştırmaya 817 öğrenci katılmıştır. Ancak anketi tam olarak doldurmayan 6 öğrenci araştırmadan dışlanmıştır. Toplam 811 öğrenci anketi tam olarak doldurmuştur.

2.1.2 Rosenberg Benlik Saygısı Ölçeği: Rosenberg tarafından geliştirilmiş bir ölçektir. Ölçek 12 alt alandan oluşmakta olup, ilk 10 madde benlik saygısını ölçmektedir [11]. Bu çalışmada öğrencilerin benlik saygısını ölçmek için benlik saygısı alt testi olan bu 10 madde kullanılmıştır. Ölçekte beş pozitif ve beş negatif ifade içeren maddeler bulunmaktadır. Ölçeğe verilen yanıtlar dörtlü likert skalası ( $1=$ çok doğru- $4=$ çok yanlış) ile değerlendirilmektedir. Benlik saygısı alt testinde 0-1 puan alanların "yüksek", 2-4 puan alanların "orta", 5-6 puan alanların ise "düşük" benlik saygısına sahip oldukları kabul edilir. Ölçeğin Türkçe geçerlik ve güvenirlik çalışması Çuhadaroğlu tarafından yapılmıştır [12].

Araştırmanın bağımlı değişkeni öğrencilerin benlik saygısı düzeyidir. Bağımsız değişkenleri ise öğrencilerinin yaşı, cinsiyeti, ailenin eğitimi ve ekonomik durumu, çocukluğunda en uzun süre yaşadığ yerleşim yeri, öğrencinin gelir algısı ve yaşadığı yer, yaşam kalitesi ve genel sağlık algısı, okuduğu programı tercih nedenleri ve programa

yönelik görüşleri, mesleğe yönelik kaygı varlığı ve kaygı nedenleridir.

Veriler SPSS for Windows 20.0 istatistik paket programı aracılığıyla çözümlenmiştir. Gruplanmış değişkenler sayı ve yüzde dağılımlarıyla sunulmuştur. Değişkenlerin normal dağılıma uygunluğu KolmogorovSmirnov testi ile yapılmış ve verilerin normal dağılım gösterdiği belirlenmiştir. İstatistiksel çözümlemede bağımsız değişkenlerle bağımlı değişken arasındaki ilişkiyi belirlemede ki-kare analizi kullanılmıştır. İstatistiksel anlamlılık düzeyi $\mathrm{p}<0,05$ olarak kabul edilmiştir. 


\section{Bulgular}

Araştırmaya katılan öğrencilerin (n=811) \%33,3'ü erkek, \%66,7'si kadın olup, yaş ortalaması $19,9 \pm 2,01$ 'dir. Öğrencilerin \%43,4'ü çocukluğunda ilde, \%36,7'si ilçede, \%19,9'u ise köyde yaşadığını, $\% 8,1$ 'i ailesinin ekonomik durumunu 'kötü' olarak, $\% 1,1$ 'i ise 'çok kötü' olarak algıladığını, \%42,8'i

Tablo 1. Öğrencilerin bazı sosyodemografik ve bireysel özelliklerinin benlik saygısı düzeyine etkisi

\begin{tabular}{|c|c|c|c|c|c|c|}
\hline \multirow{3}{*}{\multicolumn{2}{|c|}{ Özellikler $(\mathrm{n}=\mathbf{8 1 1})$}} & \multicolumn{4}{|c|}{ Benlik saygısı } & \multirow{5}{*}{$\frac{\mathbf{P}}{0,523}$} \\
\hline & & \multicolumn{2}{|c|}{ Yüksek } & \multicolumn{2}{|c|}{ Orta } & \\
\hline & & $\mathbf{n}$ & $\%$ & $\mathbf{n}$ & $\%$ & \\
\hline \multirow[t]{2}{*}{ Yaş } & $\leq 19$ yaş & 232 & 53,6 & 201 & 46,4 & \\
\hline & $\geq 20$ yaş & 211 & 55,8 & 167 & 44,2 & \\
\hline \multirow[t]{2}{*}{ Cinsiyet } & Erkek & 161 & 59,6 & 109 & 40,4 & \multirow[t]{2}{*}{$\mathbf{0 , 0 4 3}$} \\
\hline & Kadın & 282 & 52,1 & 259 & 47,9 & \\
\hline \multirow[t]{3}{*}{ Kaldığı yer } & Aile ile birlikte & 162 & 57,0 & 122 & 43,0 & \multirow[t]{3}{*}{0,597} \\
\hline & Evde & 99 & 53,2 & 87 & 46,8 & \\
\hline & Yurtta & 182 & 53,4 & 159 & 46,6 & \\
\hline \multirow[t]{4}{*}{ Babanın öğrenimi } & Okur yazar-İlkokul & 158 & 50,3 & 156 & 49,7 & \multirow[t]{4}{*}{0,040} \\
\hline & Orta & 97 & 54,5 & 81 & 45,5 & \\
\hline & Lise & 129 & 59,7 & 87 & 40,3 & \\
\hline & Üniversite & 62 & 60,2 & 41 & 39,8 & \\
\hline \multirow[t]{4}{*}{ Annenin öğrenimi } & Okur yazar-İlkokul & 226 & 52,9 & 201 & 47,1 & \multirow[t]{4}{*}{0,342} \\
\hline & Orta & 88 & 55,0 & 72 & 45,0 & \\
\hline & Lise & 103 & 60,2 & 68 & 39,8 & \\
\hline & Üniversite & 26 & 49,1 & 27 & 50,9 & \\
\hline \multirow{3}{*}{$\begin{array}{l}\text { Çocuklukta } \\
\text { yaşanan yer }\end{array}$} & İl & 222 & 59,4 & 152 & 40,6 & \multirow[t]{3}{*}{$\mathbf{0 , 0 0 1}$} \\
\hline & İlçe & 151 & 54,7 & 125 & 45,3 & \\
\hline & Köy & 70 & 43,5 & 91 & 56,5 & \\
\hline \multirow{3}{*}{$\begin{array}{l}\text { Ailesinin } \\
\text { ekonomik durumu } \\
\text { algısı }\end{array}$} & Çok iyi-iyi & 108 & 62,8 & 64 & 37,2 & \multirow[t]{3}{*}{0,004} \\
\hline & Orta & 302 & 53,5 & 262 & 46,5 & \\
\hline & Kötü- çok kötü & 33 & 44,0 & 42 & 56,0 & \\
\hline \multirow{2}{*}{$\begin{array}{l}\text { Öğrencinin gelir } \\
\text { algısı }\end{array}$} & Gelirim giderimi karş1lıyor & 281 & 60.6 & 183 & 39.4 & \multirow[t]{2}{*}{$\mathbf{0 , 0 0 1}$} \\
\hline & Gelirim giderimi karşılamıyor & 162 & 46.7 & 185 & 53.3 & \\
\hline \multirow{3}{*}{$\begin{array}{l}\text { Yaşam kalitesi } \\
\text { algısı }\end{array}$} & Çok kötü- biraz kötü & 42 & 33,9 & 82 & 66,1 & \multirow[t]{3}{*}{$\mathbf{0 , 0 0 1}$} \\
\hline & Ne iyi, ne kötü & 288 & 56,1 & 225 & 43,9 & \\
\hline & Oldukça iyi- çok iyi & 113 & 64,9 & 61 & 35,1 & \\
\hline \multirow[t]{3}{*}{ Genel sağlık algısı } & $\begin{array}{l}\text { Hiç hoşnut değilim- çok az } \\
\text { hoşnutum }\end{array}$ & 66 & 39,3 & 102 & 60,7 & \multirow[t]{3}{*}{$\mathbf{0 , 0 0 1}$} \\
\hline & Ne hoşnut, ne de değilim & 127 & 50,2 & 126 & 49,8 & \\
\hline & Oldukça hoşnutum-çok hoşnutum & 250 & 64,1 & 140 & 35,9 & \\
\hline
\end{tabular}

Araştırmaya katılan öğrencilerin \%54,6'sının benlik saygısı düzeyi 'yüksek', \%45,4'ünün ise 'orta' olarak bulunmuş, 'düşük' düzeyde benlik saygısı olan öğrenci bulunmamıştır. Erkek öğrencilerin benlik saygısı düzeyi k1z öğrencilerden daha yüksektir artmaktadır $(\mathrm{p}<0,05)$. Geliri giderini karşıladığını belirten öğrencilerin benlik saygısı düzeyi geliri giderini karşılamadığını belirten öğrencilerden daha yüksektir $(\mathrm{p}<0,01$, Tablo 1). Öğrencilerin okuduğu program türü ile benlik saygısı düzeyi arasında ilişki saptanmamıştır $\quad(\mathrm{p}>0,05) \quad$ (Tablolarda gösterilmemiştir).

Öğrencilerin okulu tercih nedenleri incelendiğinde okuduğu bölümü isteyerek seçen, kaydını yaptırmadan önce bölümle ilgili ön araştırma yapan, kendini bu mesleğe uygun bulan, mesleğiyle ilgili gelirinin giderini karşılamadığını belirtmiştir. Öğrencilerin \%10,9'u yaşam kalitesinin 'biraz kötü' olduğunu, \%4,4'ü 'çok kötü’ olduğunu, \%14,1'i genel sağlık durumundan 'çok az hoşnut', \%6,7'si ise 'hiç hoşnut değil' olduğunu belirtmiştir (Tablolarda gösterilmemiştir). $(\mathrm{p}<0,05)$. Babasının öğrenim düzeyi arttıkça, çocuklukta yaşanan yerleşim yeri büyüdükçe, ailesinin ekonomik durumu algısı ve öğrencinin yaşam kalitesi algısı arttıkça öğrencilerde yüksek benlik saygisı oranı da görev tanımını bilen öğrencilerin benlik saygısı düzeyi daha yüksek bulunmuştur ( $\mathrm{p}<0,05$, Tablo 2 ).

Mezuniyet sonrası yapacağı mesleğe yönelik kaygısı olmayan öğrencilerin benlik saygısı düzeyi daha yüksektir $(p<0,05)$. Öğrencilerin mesleğe yönelik kaygı nedenleri incelendiğinde hastalarla iletişimden korkmayanlarda, 'Bu mesleği iyi yapamayacağımı düşünüyorum' seçeneğini 'Hayır' olarak yanıtlayanlarda ve ağır koşullarda çalışmak zorunda kalma kaygısı olmayanlarda benlik saygısı düzeyi daha yüksek bulunmuştur ( $\mathrm{p}<0,01$, Tablo 3 ). 
Tablo 2. Öğrencilerin okuduğu programı tercih nedenleri ve programa yönelik görüşleri ile benlik saygısı düzeyi arasındaki ilişki

\begin{tabular}{|c|c|c|c|c|c|c|}
\hline \multirow{3}{*}{ Faktörler } & \multirow{3}{*}{ Yanitlar } & \multicolumn{4}{|c|}{ Benlik Saygısı } & \multirow{3}{*}{$\mathbf{P}$} \\
\hline & & \multicolumn{2}{|c|}{ Yüksek } & \multicolumn{2}{|c|}{ Orta } & \\
\hline & & $\mathbf{n}$ & $\%$ & $\mathbf{n}$ & $\%$ & \\
\hline \multirow{2}{*}{$\begin{array}{l}\text { Bu mesleği yapabileceğinizi } \\
\text { düşündüğünüz için mi tercih ettiniz? }\end{array}$} & Evet & 195 & 57.5 & 144 & 42.5 & \multirow[t]{2}{*}{0.160} \\
\hline & Hayır & 248 & 52.5 & 224 & 47.5 & \\
\hline \multirow[t]{2}{*}{ Bu bölümü isteyerek mi seçtiniz? } & Evet & 334 & 57.1 & 251 & 42.9 & \multirow[t]{2}{*}{0.023} \\
\hline & Hayır & 109 & 48.2 & 117 & 51.8 & \\
\hline \multirow{2}{*}{$\begin{array}{l}\text { Kaydınızı yaptırmadan önce bölümle } \\
\text { ilgili ön araştırma yaptınız mı? }\end{array}$} & Evet & 373 & 56.4 & 288 & 43.6 & \multirow[t]{2}{*}{$\mathbf{0 . 0 3 0}$} \\
\hline & Hayır & 70 & 46.7 & 80 & 53.3 & \\
\hline \multirow{2}{*}{$\begin{array}{l}\text { Programin adı tercihinizde etkili oldu } \\
\text { mu? }\end{array}$} & Evet & 220 & 52.9 & 196 & 47.1 & \multirow[t]{2}{*}{0.307} \\
\hline & Hayır & 223 & 56.5 & 172 & 43.5 & \\
\hline \multirow{2}{*}{$\begin{array}{l}\text { Üniversitenin adı tercihinizde etkili } \\
\text { oldu mu? }\end{array}$} & Evet & 385 & \begin{tabular}{|l|}
54.2 \\
\end{tabular} & 325 & \begin{tabular}{|l|}
45.8 \\
\end{tabular} & \multirow[t]{2}{*}{0.546} \\
\hline & Hayır & 58 & 57.4 & 43 & 42.6 & \\
\hline \multirow{2}{*}{$\begin{array}{l}\text { İleride bu mesleği yapmayı düşünüyor } \\
\text { musunuz? }\end{array}$} & Evet & 359 & 56.0 & 282 & 44.0 & \multirow[t]{2}{*}{0.125} \\
\hline & Hayır & 84 & 49.4 & 86 & 50.6 & \\
\hline \multirow{2}{*}{$\begin{array}{l}\text { Kendinizi bu mesleğe uygun buluyor } \\
\text { musunuz? }\end{array}$} & Evet & 379 & 56.5 & 292 & 43.5 & \multirow[t]{2}{*}{0.020} \\
\hline & Hayır & 64 & \begin{tabular}{|l|}
45.7 \\
\end{tabular} & 76 & \begin{tabular}{|l|}
54.3 \\
\end{tabular} & \\
\hline \multirow{2}{*}{$\begin{array}{l}\text { Mesleğinizle ilgili görev tanımınızı } \\
\text { biliyor musunuz? }\end{array}$} & Evet & 427 & \begin{tabular}{|l|}
55.7 \\
\end{tabular} & 340 & \begin{tabular}{|l|l|} 
\\
\end{tabular} & \multirow[t]{2}{*}{0.012} \\
\hline & Hayır & 16 & 36.4 & 28 & 63.6 & \\
\hline
\end{tabular}

Tablo 3. Öğrencilerin mezuniyet sonrası yapacağı mesleğe yönelik kaygısı ve kaygı nedenleri ile benlik saygısı

\begin{tabular}{|c|c|c|c|c|c|c|}
\hline \multirow[t]{3}{*}{ Kaygı ve nedenleri } & \multirow{3}{*}{ Yanitlar } & \multicolumn{4}{|c|}{ Benlik Saygısı } & \multirow{3}{*}{$\mathbf{P}$} \\
\hline & & \multicolumn{2}{|c|}{ Yüksek } & \multicolumn{2}{|c|}{ Orta } & \\
\hline & & $\mathbf{n}$ & $\%$ & $\mathbf{n}$ & $\%$ & \\
\hline \multirow[t]{2}{*}{ Mesleğe yönelik kaygılarınız var mı? } & Evet & 395 & 53.5 & 344 & 46.5 & \multirow[t]{2}{*}{$\mathbf{0 . 0 3 2}$} \\
\hline & Hayır & 48 & 66.7 & 24 & 33.3 & \\
\hline \multirow[t]{2}{*}{ Hastalarla ilgilenmek zor bir iş } & Evet & 80 & 51.6 & 75 & 48.4 & \multirow[t]{2}{*}{0.402} \\
\hline & Hayır & 363 & 55.3 & 293 & 44.7 & \\
\hline \multirow[t]{2}{*}{ Hastalarla temas (iletişim) beni korkutuyor } & Evet & 29 & 40.3 & 43 & 59.7 & \multirow[t]{2}{*}{$\mathbf{0 . 0 1 0}$} \\
\hline & Hayır & 414 & 56.0 & 325 & 44.0 & \\
\hline \multirow{2}{*}{$\begin{array}{l}\mathrm{Bu} \text { mesleği } \quad \text { iyi } \quad \text { yapamayacağımı } \\
\text { düşünüyorum }\end{array}$} & Evet & 64 & 43.8 & 82 & 56.2 & \multirow[t]{2}{*}{0.004} \\
\hline & Hayır & 379 & 57.0 & 286 & 43.0 & \\
\hline \multirow{2}{*}{$\begin{array}{l}\text { Mesleğimi yaparken şiddete uğrama } \\
\text { kaygısı }\end{array}$} & Evet & 51 & 55.4 & 41 & 44.6 & \multirow[t]{2}{*}{0.868} \\
\hline & Hayır & 392 & 54.5 & 327 & 45.5 & \\
\hline \multirow{2}{*}{$\begin{array}{l}\text { Ağır koşullar altında çalışmak zorunda } \\
\text { kalma kaygısı }\end{array}$} & Evet & 89 & 45.6 & 106 & 54.4 & \multirow[t]{2}{*}{$\overline{0.004}$} \\
\hline & Hayır & 354 & 57.5 & 262 & 42.5 & \\
\hline \multirow[t]{2}{*}{ İş bulamama kaygısı } & Evet & 330 & 55.6 & 264 & 44.4 & \multirow[t]{2}{*}{0.378} \\
\hline & Hayır & 113 & 52.1 & 104 & 47.9 & \\
\hline
\end{tabular}

\section{Tartışma}

Benlik saygısı bireyin kendine karşı olumlu ya da olumsuz tavr1. bireyin kendini yeterli ve önemli olarak algılamasını ifade etmektedir [1]. Geleceğin sağlık teknikerlerinin benlik saygısını etkileyen etmenlerin belirlenmesi ve saptanan sorunların çözümlenmesi. topluma sunulan sağlık hizmeti kalitesini doğrudan ve dolaylı olarak etkileyebilir. $\mathrm{Bu}$ çalışmada geleceğin sağlık teknikerlerinin benlik saygısı düzeyi ve ilişkili etmenler incelenmiştir.

Araştırmaya katılan öğrencilerin yaklaşık yarısının benlik saygısı düzeyi yüksektir. Erkek öğrencilerde. babasının öğrenim düzeyi yüksek olanlarda. çocukluğunda büyük kentte yaşayanlarda. ailesinin ekonomik durumu iyi olanlarda. gelirini yüksek olarak algılayanlarda. yaşam kalitesini iyi-çok iyi olarak algılayanlarda benlik saygısı yüksek bulunmuştur. Programa kaydını yaptırmadan önce bölümle ilgili ön araştırma yapan. kendini bu mesleğe uygun bulan. mesleğiyle ilgili görev tanımını bilen. mezuniyet sonrası yapacağı mesleğe yönelik kaygısı olmayan öğrencilerin. hastalarla iletişim ve ağır koşullarda çalışmak zorunda kalma kaygısı olmayan öğrencilerin benlik saygısı düzeyi daha yüksektir.

Araştırma grubunda düşük benlik saygısı olan öğrencinin bulunmaması iyimser bir bulgu olmakla birlikte. öğrencilerin yaklaşık yarısının benlik saygısı 'orta' düzeyde olarak bulunmuştur. İki farklı üniversitede ebelik ve hemşirelik öğrencilerinde yapılan çalışmalarda [13.14] ve Muğla Üniversitesi 
öğrencilerinde yapılan diğer bir çalışmada [4] yüksek benlik saygısı oranı bizim çalışmamızdan fazladır. Manisa'da 14-19 yaş grubu lise öğrencilerinde yapılan bir çalışmada ise öğrencilerin üçte ikisinin benlik saygısı düşük. yalnızca \%6.4'ünün benlik saygısı yüksek bulunmuştur [9]. Gençlerin benlik saygısı düzeyine sosyodemografik faktörler. geçmiş yaşantısı. deneyimi. aile ve toplumsal statü gibi pek çok değişkenin etkisi olabilir.

Araştırmamıza katılan erkek öğrencilerin benlik saygısı düzeyi kız öğrencilerden daha yüksektir. Yapılan çalışmaların bazılarında öğrencilerin cinsiyetiyle benlik saygısı düzeyi arasında ilişki bulunmamış [7.15-17]. bazılarında ise bizim bulgumuzla benzer nitelikte erkek öğrencilerde benlik saygısı düzeyi daha yüksek bulunmuştur [4.8]. Adnan Menderes Üniversitesi öğrencilerinde yapılan bir çalışmada ise kız öğrencilerde benlik saygısı düzeyinin daha yüksek olduğu saptanmış. bu sonucun toplumdaki cinsiyet rolleriyle ilişkili olabileceği belirtilmiştir [2]. Kültürümüzdeki cinsiyete bağlı roller ve bu rollere yönelik beklentilerdeki belirgin ayrımların kız ve erkek öğrencilerin benlik saygısı düzeyindeki farklılığa etkisi olabilir.

Benlik saygısında ailenin önemli bir yeri vardır [1.6]. Anne-babanın eğitim düzeyi yükseldikçe çocukların da benlik saygıları artmakta özgüven duyguları gelişmektedir [4.18]. Araştırmamızda babanın öğrenim düzeyi arttıkça yüksek benlik saygısı olan öğrencilerin oranının da arttığı görülmüştür. Muğla Üniversitesi'nde yapılan bir çalışmada bizim çalışmamızla uyumlu bulgular saptanmış [4]. ancak hemşirelik ve ebelik öğrencilerinde yapılan bir başka çalışmada ebeveynin eğitim düzeyi ile öğrencinin benlik saygısı arasında ilişki saptanmamıştır [14]. Araştırmamızda öğrencinin çocuklukta yaşadığ 1 yer. ailesinin ekonomik durumu algısı. öğrencinin kendi gelirine yönelik algısı ve yaşam kalitesi algısı ile yüksek benlik saygısı arasında anlamlı ilişki bulunmuştur. Literatürde ailesinin sosyoekonomik ve sosyokültürel düzeyinin öğrencinin benlik saygısı düzeyine etkisinin olmadığını ortaya koyan çalışmalar vardır [7.16.17]. Pakistan'da üniversite öğrencilerinde yapılan bir çalışmada bizim bulgumuzla uyumlu olarak ailenin gelir düzeyi arttıkça ve öğrencinin cep harçlığı miktarı arttıkça benlik saygısı düzeyinin arttığı saptanmıştır [8]. Ülkemizde üniversite öğrencilerinde yapılan çalışmalarda ekonomik sorunu olmayanlarda [2.14.18.19]. çocukluğunda şehirde yaşayanlarda [14]. sağlığını "iyi” olarak algılayanlarda [19]. yaşantısından memnun ve geleceğinden umutlu olanlarda [2] benlik saygısının daha yüksek olduğu saptanmıştır. Çalışan gençlerde yapılan bir çalışmada ailedeki kararlara katılım arttıkça gençlerin benlik saygısı düzeyinin de arttığı saptanmıştır [17].
Ailelerin ekonomik ve sosyal düzeyinin yanısıra çocuğun ailedeki değerinin de çocukların benlik saygısına etkisi olduğu bilinmektedir [10].

Öğrencilerin gelecekte yapacağı mesleğe yönelik bireysel kararlılıkla üniversiteye girmeleri hem öğrenimi sırasındaki akademik başarıyı hem de mesleğe yönelik pozitif alg1 ve isteği etkileyebilir. Araştırmamızda öğrencilerin okulu tercih nedenleri incelendiğinde okuduğu bölümü isteyerek seçen. kaydını yaptırmadan önce bölümle ilgili ön araştırma yapan. kendini bu mesleğe uygun bulan. mesleğiyle ilgili görev tanımını bilen öğrencilerin benlik saygısı düzeyi daha yüksek bulunmuştur. Adnan Menderes Üniversitesinde yapılan bir çalışmada öğrencinin okuduğu bölümü sevip sevmemesi ile benlik saygısı düzeyi arasında ilişki saptanmamıştır [2]. Hiçdurmaz ve ark. [10] üniversite öğrencilerinde yaptıkları çalışmada üniversitede okuduğu bölümü isteyerek seçenlerde benlik saygısının daha yüksek olduğu saptanmıştır. Sağlık hizmetleri meslek yüksekokulu öğrencilerinde yapılan bir çalışmada ise üniversiteyi seçme nedenleri ile benlik saygısı düzeyi arasında ilişki saptanmazken. okuduğu bölümden memnun olmayan öğrencilerin benlik saygısı düzeyinin daha yüksek olduğu saptanmıştır [7]. Özgüngör ve ark. [20]. üniversite öğrencilerindeki yüksek benlik saygısı ile içsel hedef düzenleme. bölüm tercihi. bölüme yönelik olumlu tutum. görev değeri ve akademik başarı arasında pozitif ilişki saptamışlardır.

Benlik saygısı düzeyi öğrencinin meslek tercihini. görev bilincini ve sosyal ilişkilerini de etkileyebilmektedir. Literatürde. sosyal ilişkilerde doyum [21]. algılanan sosyal destek azlığı [22]. yalnızlık [21.23]. umutsuzluk [2.9]. internet bağımlılığı ve depresyon [24]. akademik başarısızlık [6] ile düşük benlik saygısı arasında ilişki saptanmıştır. Bizim araştırma grubumuz gibi sağlık hizmetleri meslek yüksekokulu öğrencilerinde yapılan bir çalışmada benlik saygısı ile yardımseverlik ve atılganlık düzeyleri arasında pozitif yönde ilişki olduğu saptanmıştır [7].

Yüksek benlik saygısının öğrencilerin ruh sağlığında koruyucu etkisi olduğu [1]. aynı zamanda duygusal gelişmesinde ve özerkleşmesinde de etkisi olduğu belirtilmektedir [25]. Araştırmamızda mezuniyet sonrası yapacağı mesleğe yönelik kaygısı olmayan öğrencilerin benlik saygısının daha yüksek olduğu bulunmuştur. Üniversiteye hazırlanan lise öğrencilerinde yapılan bir çalışmada anksiyetenin benlik saygısını azalttığı saptanmıştır [15]. Araştırmamıza katılan öğrencilerin mesleğe yönelik kayg1 nedenleri incelendiğinde hastalarla iletişimden korkanların. seçtiği mesleği iyi yapamayacağını düşünenlerin. mesleği yapmaya başladığında ağır koşullarda çalışmak zorunda kalma kaygısı olanların 
benlik saygısı düzeyinin daha düşük olduğu görülmüştür. Hemşirelik öğrencilerinde yapılan bir çalışmada stresle başa çıkmada yüksek benlik saygısının önemli bir gösterge olduğu saptanmıştır [5]. Öğrencilerin başarılı ve mutlu olabilmeleri için ruh sağlığının yerinde olması ve benlik saygısı düzeyinin yüksek olması önemlidir. Sağlık alanında öğrenim gören öğrencilerin eğitim sırasındaki yüksek özgüveni. hastalarla güçlü ve terapötik ilişkilerin geliştirilmesi için çok önemlidir [26].

\section{Sonuç}

Sonuç olarak. öğrencilerin sosyodemografik özellikleri. ekonomik durum ve yaşam kalitesi algısı. okudukları programı tercih nedenleri ve programa yönelik olumlu görüşleri ve mesleğe yönelik kaygı düzeyi ile yüksek benlik saygısı düzeyi arasında ilişki bulunmuştur. Öğrencilerin benlik saygısının artırılması için ailesel ve eğitsel kökenli ruh sağlığını etkileyen faktörlerin belirlenerek koruyucu hizmetlerin bütüncül olarak sunulmasında yarar vardır. Benlik saygısını etkileyen eğitsel ve sosyal sorunların çözümlenmesi için çaba harcanması ve gençler için ruh sağlığını koruyucu bir eğitim ortamı oluşturulması gerekmektedir. Öğrencilerin üniversite öğrenimi sırasında sosyoekonomik ve sosyokültürel eşitsizlikler göz önüne alınarak burs olanaklarının artırılması öğrencilerin özgüven kazanarak benlik saygısı düzeyinin artmasında etkili olabilir.

Öğrencilerin benlik saygısını etkileyen etmenlerin daha net saptanabilmesi için retrospektif vaka-kontrol çalışmaları yapılabilir. Eğitim ve sosyal yaşantısında sorun yaşayan öğrencilere sorunlarla baş etme ve benlik saygısını artırmaya yönelik eylem planları ve uygulamalar yapılabilir. Örneğin okullarda öğrencilerin kolayca ulaşabileceği psikologlar görevlendirilebilir. Belirli aralıklarla öğrencilerin ruh sağlığ değerlendirilebilir. $\mathrm{Bu}$ hizmetlerin sürekliliği öğrencilerin ruh sağlı̆̆ için önemlidir. Üniversiteye yerleşmeden önce gençlere mesleklerin özellikleri. görev tanımı ve karşılaşılabilecek sorunlar. bireysel hedeflere uygun meslek seçimi hakkında danışmanlık hizmeti sunulabilir.

\section{Kaynaklar}

1. Aslan-Yılmaz H. Bir derleme: Benlik kavramına ilişkin bazı yaklaşımlar ve tanımlamalar. Sosyal Bilimler Dergisi. 2016. 48. 79-89.

2. Öner Altıok H. Ek N. Koruklu N. Üniversite öğrencilerinin benlik saygı düzeyi ile ilişkili bazı değişkenlerin incelenmesi. Adnan Menderes Üniversitesi Ë̆itim Fakültesi Eğitim Bilimleri Dergisi. 2010; 1(1): 99-120.

3. Tin ST. Sherina MS. et al. Prevalence and predictors of suicidality among medical students in a public university. Med J Malaysi. 2015. 70(1). 1-5.

4. Baybek H. Yavuz S. Muğla Üniversitesi öğrencilerinin benlik saygılarının incelenmesi. Muğla Üniversitesi SBE Dergisi. 2005. 14. 73-95.

5. Yıldırım N. Karaca A. et al. The relationship between educational stress. stress coping. self-esteem. social support. and health status among nursing students in Turkey: A structural equation modeling approach. Nurse Educ Today. 2017. 48. 33-39.

6. D'Mello L. Monteiro M. Pinto N. A study on the self esteem and academic performance among the students. IJHSP. 2018. 2(1). 1-7.

7. Kılınç E. Kılıç M. İpekçi NN. Sağlık hizmetleri meslek yüksekokulu öğrencilerinin benlik saygısı. atılganlık ve özgecilik düzeyleri ile aralarındaki ilişsinin incelenmesi. Karadeniz Sosyal Bilimler Dergisi. 2016. 15(8). 379-398.

8. Haq MA. Association Between Socio-Demographic Background and Self-Esteem of University Students. Psychiatr Q. 2016. 87. 755-762.

9. Özmen D. Erbay Dündar P. ve ark. Lise öğrencilerinde umutsuzluk ve umutsuzluk düzeyini etkileyen Etkenler. Anadolu Psikivatri Derg. 2008. 9. 8-15.

10. Hiçdurmaz D. İnci F. Karahan S. Predictors of mental health symptoms. automatic thoughts. and self-esteem among university students. Psychol Re.. 2017. 4. 650-69.

11. Gray-Little B. Williams VSL. Hancock TD. An item response theory analysis of the Rosenberg Self-Esteem Scale. Pers Soc Psychol Bull.1997. 23. 443-451.

12. Çuhadaroğlu F. Adolesanlarda benlik saygısı. [Yüksek Lisans Tezi]. Ankara. Hacettepe Üniversitesi Sağlık Bilimleri Enstitüsü.1985.

13. Arslan Özkan İ. Özen A. Öğrenci hemșirelerde boyun eğici davranışlar ve benlik saygısı arasındaki ilişki. TAF Prev Med Bull. 2008. 7(1). 53-58.

14. Dinçer F. Öztunç G. Hemşirelik ve ebelik öğrencilerinin benlik saygısı ve atılganlık düzeyleri. Sağllk Bilimleri Fakültesi Hemsirelik Dergisi. 2009. 16(2). 22-33.

15. Sarı SA. Bilek G. Çelik E. The anxiety and self-esteem in senior high school students: a cross-sectional study. Nord $J$ Psychiatry. 2018. 72 (2). 84-88.

16. Kılınç FE. Investigation of the relationship between selfesteem and metacognitive awareness level of 9th grade students. Procedia-Soc Behav Sci. 2013. 106. 1622-1628.

17. Sala Razı G. Kuzu A. Calıșan gençlerde benlik saygısı iletişim becerileri ve stresle baş etme. TAF Prev Med Bull. 2009. 8(1). 17-26.

18. Yiğit $\mathrm{H}$. Ergenlerin benlik saygılarının yașam doyumu ve bazı özlük nitelikleri açısından incelenmesi [Yüksek Lisans Tezi]. Konya. Selçuk Üniversitesi Eğitim Bilimleri Enstitüsü. 2010.

19. Karadağ G. Güner İ. ve ark. Gaziantep Üniversitesi Sağlık Yüksekokulu hemşirelik öğrencilerinin benlik saygıları. Firat Sağllk Hizmetleri Dergisi. 2008. 3(7): 29-42.

20. Özgüngör S. Duatepe Paksu A. Üniversite öğrencilerinde benlik saygısı düzeyine göre akademik başarıyı yordayan değişkenler. Türk Psikolojik Danışma ve Rehberlik Dergisi. 2017. 7(48). 111-125.

21. Yöyen E. Üniversite öğrencilerinin benlik saygısı ve yalnızlık düzeylerinin incelenmesi. Kastamonu Eğitim Dergisi. 2017. 25 (6). 2185-2198

22. Zou J. Associations between trait emotional intelligence and loneliness in Chinese undergraduate students: mediating effects of self-esteem and social support. Psychol Rep. 2014. 114(3). 880-890.

23. Güllüoğlu B. Karaırmak Ö. Üniversite öğrencilerinde yalnızlı̆̆ın yordayıcısı olarak benlik saygısı ve psikolojik sağlamlık. Ege Eğitim Dergisi. 2010. 2 (11). 73-88.

24. Nie J. Zhang W. Liu Y. Exploring depression. self-esteem and verbal fluency with different degrees of internet addiction among Chinese college students. Compr Psychiatry. 2017. 72. 114-120.

25. Karaırmak Ö. Siviş-Cetinkaya R. Benlik saygısının ve denetim odağının psikolojik sağlamlık üzerine etkisi: Duyguların aracı rolü. Türk Psikolojik Danışma ve Rehberlik Dergisi. 2011. 4(35). 30-43.

26. Edwards D. Burnard P. et al. A longitudinal study of stress and self-esteem in student nurses. Nurse Educ Today. 2010. 30(1). 78-84 
http://edergi.cbu.edu.tr/ojs/index.php/cbusbed

isimli yazarın CBU-SBED başlıklı eseri bu

Creative Commons Alint1-Gayriticari4.0

Uluslararası Lisansı ile lisanslanmıştır.

(c) (1) (9) 